Hill ore body, Australia (Plimer, 1983). It seems therefore worthwhile to look closer at the supracrustal rocks at Isuamiut and at their conterparts on the mainland in order to locate interesting mineralisation such as massive sulphide ore bodies.

Acknowledgements. J. Rønsbo, Mineralogical Institute, University of Copenhagen made the microprobe analyses of the tourmalines. The microprobe was bought with funds from the Danish Natural Science Council.

\section{References}

Appel, P. W. U. 1985: Strata-bound tourmaline in the Archaean Malene supracrustal belt, West Greenland. Can. J. Earth Sci. 22, 1485-1491.
Appel, P. W. U. \& Garde, A. A. 1987: Stratabound scheelite and stratiform scheelite in the Archaean Malene supracrustal rocks, southern West Greenland. Bull. Grønlands geol. Unders. 156, $26 \mathrm{pp}$.

Ellitsgaard-Rasmussen, K. 1954: On the geology of a metamorphic complex in West Greenland. Meddr Grønland 136 (6), 70 pp. (also Bull. Grønlands geol. Unders. 5).

Plimer, I. R. 1983: The association of tourmaline-bearing rocks with mineralisation at Broken Hill, NSW. Aus. Instn Min. Metall. Conf. Broken Hill N. S. W. 1983, 157-176.

Reynolds, R. C. 1965: The concentration of boron in Precambrian seas. Geochim. cosmochim. Acta 29, 1-16.

Slack, J. F. 1982. Tourmaline in Appalachian-Caledonian massive sulphide deposits and its exploration significance. Trans. Instn Mining Metall. 91, B81-B89.

Weisbrod, A. 1987: Boron content of hydrothermal solutions and tourmaline stability. Terra Cognita 7, 408-409.

\title{
Corundum crystals with blue-red colour zoning near Kangerdluarssuk, Sukkertoppen district, West Greenland
}

\author{
Adam A. Garde and Mogens Marker
}

Results are presented of field work at a corundum locality near the head of Kangerdluarssuk, east of Maniitsoq/Sukkertoppen, West Greenland. The authors carried out geological mapping and sampling over four days in August 1987 to evaluate the quality of the corundum as a possible gemstone.

\section{Previous investigations}

The corundum locality has probably been known to the local population for a long time. It was first visited by geologists in 1977 during reconnaissance mapping by GGU. The locality is mentioned by Secher et al. (1982), and by Petersen \& Secher (1985) who reported rose red bipyramidal corundum crystals up to $15 \mathrm{~cm}$ long.

\section{General geological setting}

The Sukkertoppen district, which is part of the Archaean of southern West Greenland, has only been covered by reconnaissance geological mapping at a scale of 1:500 000 (Noe-Nygaard \& Ramberg, 1961; Allaart et al., 1978; Allaart, 1982). The area consists of granulite and upper amphibolite facies, quartzofeldspathic gneisses and supracrustal rocks, mostly amphibolites and their granulite facies equivalents, as well as clastic metasediments which are common in this part of the
Archaean basement, e.g. on Hamborger Land north of Maniitsoq. Pods and lenses of ultrabasic rocks, sometimes several hundred metres long, occur within the supracrustal sequences and most commonly consist of ortho- and clinopyroxene and lesser olivine, together with $\mathrm{Mg}$-rich amphibole and various low-grade alteration products.

\section{Country rocks at the corundum locality}

In the vicinity of Kangerdluarssuk there are several sequences of supracrustal amphibolites and metasediments with local ultrabasic lenses in the gneisses. The structural trend is persistently north-east with sub-vertical dips and a strong planar fabric particularly well developed in the metasediments.

The corundum locality occurs within one of these supracrustal sequences at the contacts between two small lensoid ultrabasic bodies and a spectacular horizon of bluish and rusty kyanite-garnet schist (fig. 1). The ultrabasic bodies are situated entirely within the metasediments which are in turn intercalated between calc-silicate banded and veined amphibolites. Pegmatites composed of quartz, feldspar, mica and occasionally black tourmaline occur within the amphibolites in the vicinity of, but not immediately adjacent to, the corundum locality. 


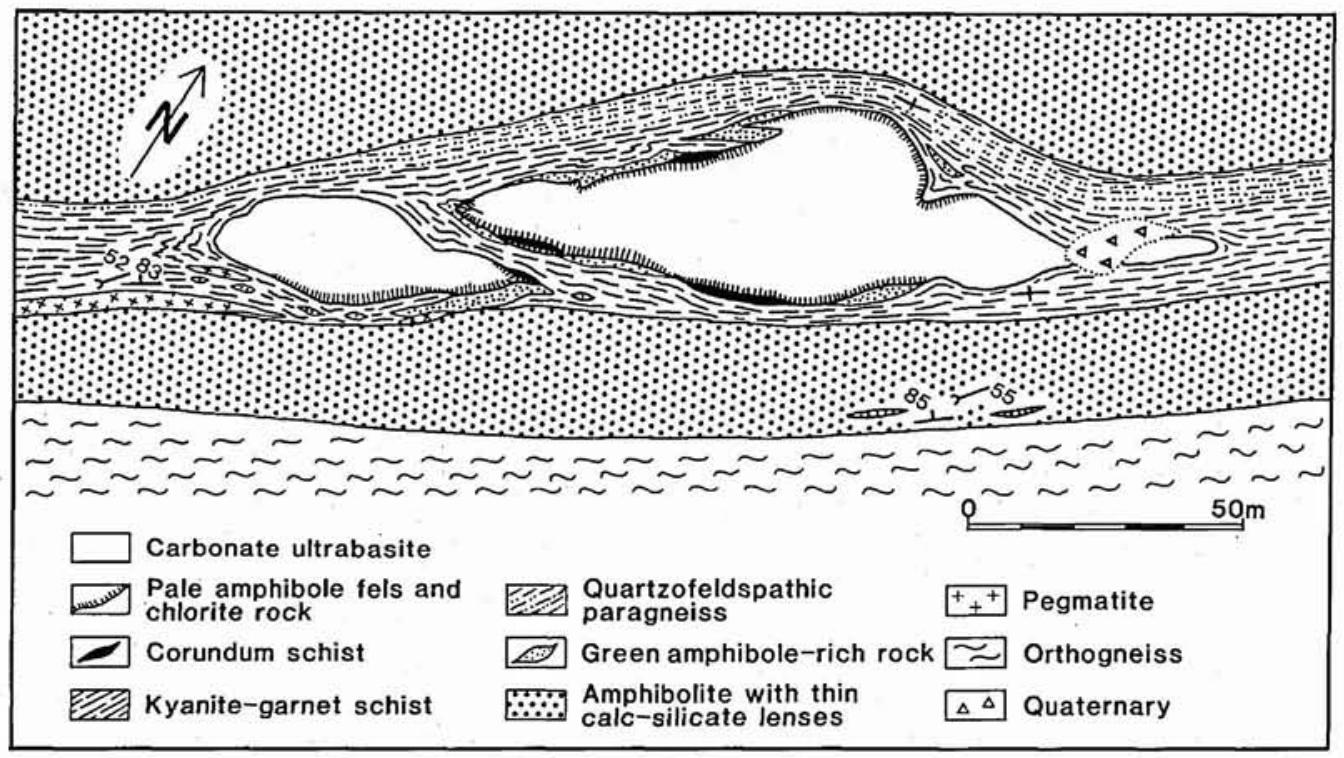

Fig. 1. Geological map of the corundum locality at Kangerdluarssuk.

The ultrabasic bodies are somewhat unusual for the West Greenland Archaean, being very olivine-rich and with appreciable amounts of interstitial carbonate. The outcrops are massive, dull grey on fresh surfaces, and have light brown weathering surfaces without the crumbling that is characteristic of most ultrabasic bodies in the region. Thin sections are dominated by subhedral fresh olivine grains up to $c .5 \mathrm{~mm}$ long with a weak preferred orientation. Interstitial carbonate, pale Mgrich orthopyroxene and amphibole are common, as well as serpentine or $\mathrm{Mg}$-rich chlorite, dark green spinel sensu lato (probably hercynite) and opaque oxide. Within the two ultrabasic bodies there are several veins up to $c .20 \mathrm{~cm}$ thick of slender prismatic to fibrous, pale brown to almost white, amphibole orientated perpendicular to vein surfaces.

The metasediments in the vicinity of the corundum locality both comprise kyanite-garnet schists and quartzofeldspathic paragneisses, with a gradual transition from one to the other over a few metres (fig. 1). The south-eastern part of the north-east striking metasedimentary unit consists of kyanite-garnet schists which are composed of alternating grey-brown quartz-feldspargarnet rich layers a few centimetres thick, and bluish rusty layers of similar thickness with red garnet spots in a pale blue matrix. The blue matrix owes its colour to aggregates of prismatic kyanite c. 1-2 mm long, with additional fine-grained biotite, plagioclase, quartz, graphite, tourmaline, rutile and apatite. Fine needles in the matrix adjacent to kyanite aggregates may be kyanite or possibly sillimanite. The abundant light'pinkish red garnets are up to $2 \mathrm{~cm}$ in size with local inclusions of staurolite. The grey quartzofeldspathic paragneisses at the north-western margin of the metasedimentary unit are uniform, weakly foliated, pale grey, fine-grained rocks consisting of quartz, plagioclase and microcline with minor biotite, muscovite, epidote and tourmaline.

\section{The corundum occurrence}

Between the two lensoid ultrabasic bodies and the kyanite-garnet schists characteristic metamorphic contact zones are developed which are at most a few metres, often only about one metre, thick. In the contact zone along the south-eastern side of the larger ultrabasic body there is a well-developed corundumbearing schist. The innermost layer, along the margin of the ultrabasic body, is a pale yellowish to greenish amphibole rock with minor serpentine or $\mathrm{Mg}$-rich chlorite, which is followed outwards by a coarse-grained greenish chlorite with or without amphibole rock with accessory graphite and rutile. Then follows a medium- to coarsegrained, brown phlogopite/biotite-amphibole-plagioclase rock with accessory apatite and zircon. Yellowgreen apatite crystals up to $4 \mathrm{~cm}$ long were found in this layer.

The mica-amphibole-plagioclase rock just described grades into a corundum schist. This rock is composed of medium- to coarse-grained biotite, abundant barrelshaped corundum porphyroblasts (about $10-20 \%$ of the rock), interstitial plagioclase and accessory graphite, rutile, tourmaline and zircon. Both graphite and rutile 
may be present in appreciable amounts. The corundum schist is about half a metre thick and extends for $c .20 \mathrm{~m}$ between the ultrabasic body and the kyanite-garnet schist. Adjacent to the corundum schists a brown staurolite-rich rock is locally developed. In this rock short prismatic staurolite prisms up to $1 \mathrm{~cm}$ in length, often with tourmaline inclusions, are set in a matrix of biotite, plagioclase, minor tourmaline and opaque oxides.

Corundum also occurs at three other, smaller outcrops at the margins of the ultrabasic bodies (fig. 1). Here the corundum crystals usually have a deeper red colour but are much smaller and not idiomorphic.

In several places at the contacts of the ultrabasic bodies there are lenses up to a few metres thick of green to almost black fine-grained rocks. The green lenses consist of graphite-rich, millimetre-banded, plagioclaseamphibole rocks, as well as massive monomineralic, dark green, fine-grained, amphibole rocks. Within the green rocks there are occasional small lenses a few centimetres thick, which consist of black spinel sensu lato (probably hercynite, as octahedra up to $2 \mathrm{~cm}$ in size), carbonate and chlorite.

The contact zones described above, like the ultrabasic bodies and the metasediments themselves, have been deformed during high grade $P-T$ conditions. The contact zones and metasediments wrap around the ultrabasic bodies and are generally distinctly foliated, and tight irregular small folds are common in the contact zones especially at the tips of the ultrabasic bodies.

\section{The corundum crystals}

The corundum crystals are quite variable. At the largest occurrence south-east of the larger ultrabasic body described above, the corundums are usually idiomorphic barrel-shaped bipyramidal crystals, $2-5 \mathrm{~cm}$ in length with irregular terminations, very rough surfaces and a coarse horizontal striation. Several weathered-out crystals between 7 and $10 \mathrm{~cm}$ long were collected, as well as one broken specimen $16 \mathrm{~cm}$ long. The corundums are never transparent but are typically zoned with bluish grey cores and pale purple rims. Individuals that are purple throughout also occur. The corundum crystals are sometimes partially overgrown with graphite and/or rutile. The latter also forms inclusions up to about $1 \mathrm{~mm}$ in size perpendicular to the corundum $c$-axis.

When cleaned corundum fragments are viewed along the $c$-axis a silky lustre in a star-like fashion is sometimes visible. This lustre may be due to frequent tiny needle-like inclusions, probably of rutile, observed in thin section under high magnification. Test polishing has shown that weak asterism is present, but all the five polished specimens also contain many inclusions of larger $(c .0 .1-1 \mathrm{~mm})$ rutile grains.

\section{Genesis of the corundum}

At present it is only possible to present a general statement of the corundum genesis. Field relations and preliminary observations of thin sections indicate that the corundum schists were produced during the highgrade Archaean regional deformation and metamorphism. We think that the corundum was produced by metamorphic desilication reactions between the ultrabasic rocks and aluminous metasediments, and that chromium supplied from the ultrabasic rocks is responsible for the red colour of the corundum. The presence of both staurolite and kyanite in rocks that are considered to be cogenetic with the corundum schists indicates minimum $P-T$ conditions of around $550^{\circ} \mathrm{C}$ and $5.5 \mathrm{~kb}$ (Winkler, 1979) during corundum growth.

Corundum of presumed metamorphic origin is known to occur elsewhere in schists adjacent to ultrabasic rocks. Schreyer et al. (1972), Ohnmacht (1974), and Cribb (1982) have described lensoid carbonate-orthopyroxenites (sagvandites) associated with amphibolites and kyanite schists from several localities in North Norway, where high-grade metamorphic corundum-bearing contact zones have developed. The above mentioned authors believe that the carbonate minerals (dolomite, magnesite and/or breunnerite, $\left.\mathrm{Mg}_{9} \mathrm{Fe}\left(\mathrm{CO}_{3}\right)_{10}\right)$ in the sagvandites formed from metasomatic interaction between ultrabasic rocks and calcareous metasediments. The descriptions of the sagvandites and their contacts resemble the Kangerdluarssuk occurrence in many respects. It is possible that the widespread calc-silicate minerals in the amphibolites adjacent to the Kangerdluarssuk occurrence indicate a former source for the carbonate material in the ultrabasic lenses, and that decarbonation reactions have played a role in corundum-forming reactions.

Acknowledgement. We thank Aage Jensen, Geological Institute, University of Copenhagen, for encouraging us to carry out this investigation, as well as for arranging the test polishing of the corundum crystals.

\section{References}

Allaart, J. H. (compiler) 1982: Geologisk kort over Grønland, 1:500 000, Sheet 2, Frederikshåb Isblink - Søndre Strømfjord. Copenhagen: Geol. Surv. Greenland.

Allaart, J. H., Friend, C. R. L., Hall, R. P., Jensen, S. B. \& Roberts, I. W. N. 1978: Continued 1:500 000 reconnaissance mapping in the Precambrian in the Sukkertoppen region, southern West Greenland. Rapp. Grønlands geol. Unders. 90, 50-54. 
Cribb, S. J. 1982: The Torsvik sagvandite body, North Norway. Norsk geol. Tidsskr. 62, 161-168.

Noe-Nygaard, A. \& Ramberg, H. 1961: Geological reconnaissance map of the country between latitudes $69^{\circ} \mathrm{N}$ and $63^{\circ} 45$ N, West Greenland. Meddr Grønland 123(5), 9 pp.

Ohnmacht, W. 1974: Petrogenesis of carbonate-orthopyroxenites (sagvandites) and related rocks from Troms, northern Norway. J. Petrology 15, 303-323.

Petersen, O. V. \& Secher, K. 1984: Grönland. Mineralien. Geologie. Geschichte. Magma 6/84, 83 pp. Bochum: Bode \& Partner KG.

Schreyer, W., Ohnmacht, W. \& Mannchen, J. 1972: Carbonate-orthopyroxenites (sagvandites) from Troms, northern Norway. Lithos 5, 345-364.
Secher, K., Nielsen, B. J. \& Knudsen, N. Ø. 1982: Grønlands smykkesten, 52 pp. Copenhagen: Den Kongelige Grønlandske Handel.

Winkler, H. G. F. 1979: Petrogenesis of metamorphic rocks. 5 th ed. 348 pp. Berlin: Springer-Verlag.

M. M., Institut for Almen Geologi, Øster.Voldgade 10, DK-1350 Copenhagen $K$, Denmark.

\title{
Border relations between the amphibolite facies Finnefjeld gneiss complex and granulite facies grey gneisses in the Fiskefjord area, southern West Greenland
}

\author{
Mogens Marker and Adam A. Garde
}

The authors carried out geological mapping in August 1987 at the south-eastern boundary of the Finnefjeld gneiss complex around $65^{\circ} \mathrm{N}$. The field work was supported by the GGU cutter 'J. F. Johnstrup'.

Based on reconnaissance mapping in the 1950 s Berthelsen $(1951,1957,1962)$ divided the Archaean gneiss terrain in the southern Sukkertoppen district between Godthåbsfjord and Søndre Isortoq into three major tectonic units: the Nordland, the Finnefjeld and the Alángua complexes. This division was also followed by Noe-Nygaard \& Ramberg (1961).

The Nordland complex of Berthelsen in the south (fig. 1) consists of mainly basic supracrustal rocks intruded by voluminous $c$. $3000 \mathrm{Ma}$ old grey tonalitic gneisses, referred to as grey gneisses by Garde et al. (1986) and Garde (in press). The supracrustal rocks and orthogneisses show complex polyphase folding and have been metamorphosed under granulite facies conditions and later partially retrograded to amphibolite facies mineral parageneses.

The Finnefjeld complex in the central part of the region mainly consists of homogeneous grey biotite- and hornblende-bearing orthogneisses with amphibolite facies mineral assemblages. Berthelsen (1957, 1962) found occasional relics of hypersthene in the Finnefjeld gneiss complex and suggested that an episode of granulite facies metamorphisn preceded the amphibolite facies episode in the whole complex.

The Alángua complex to the north (fig. 1) consists of pelitic to semipelitic schists and basic supracrustal rocks embedded in homogeneous orthogneisses. The rocks are intensively folded and metamorphosed under highgrade conditions, with garnet and sillimanite in pelitic lithologies.

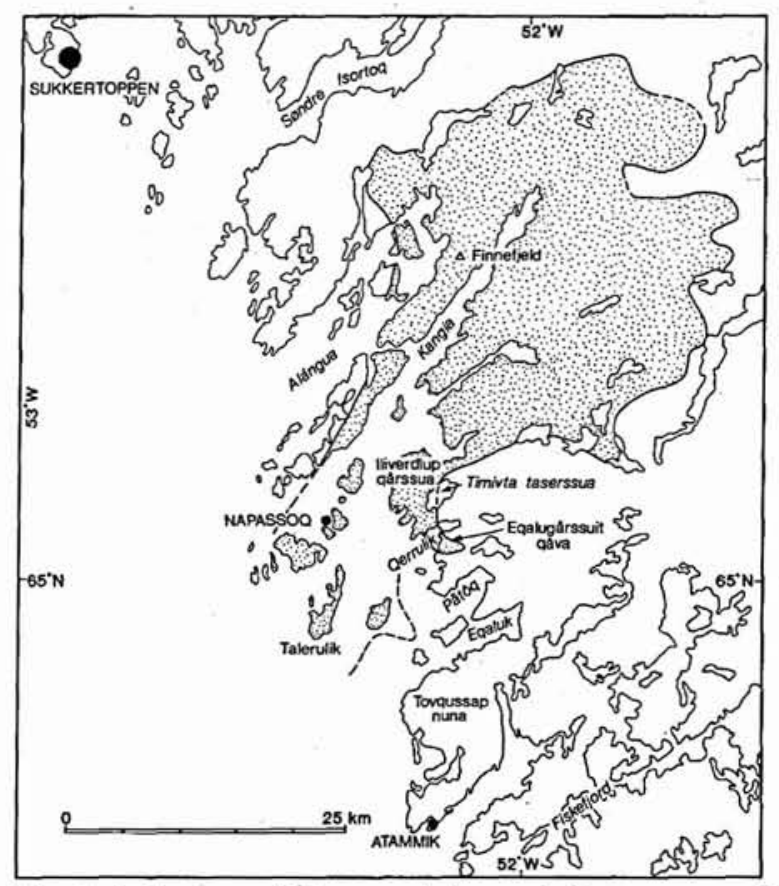

Fig. 1. Index map of the area between Sukkertoppen and Fiskefjord. The extent of the Finnefjeld gneiss complex is shown with dots. 